\title{
Informatics competencies essential to decision making in nursing management
}

\section{Competências em informática essenciais à tomada de decisão no gerenciamento em enfermagem Competencias en informática esenciales a la toma de decisión en la gestión en enfermería}

\author{
Rodrigo Jensen¹, Erika de Souza Guedes², Maria Madalena Januário Leite ${ }^{3}$
}

\section{How to cite this article:}

Jensen R, Guedes ES, Leite MMJ. Informatics competencies essential to decision making in nursing management. Rev Esc Enferm USP. 2016;50(1):109-17. DOI: http://dx.doi.org/10.1590/S0080-623420160000100015

${ }^{1}$ Universidade Estadual Paulista "Júlio de Mesquita Filho", Faculdade de Medicina de Botucatu, Botucatu, SP, Brazil.

${ }^{2}$ Universidade de São Paulo, Escola de Enfermagem, Programa de Pós-Graduação em Enfermagem na Saúde do Adulto, São Paulo, SP, Brazil.

${ }^{3}$ Universidade de São Paulo, Escola de Enfermagem, Departamento de Orientação Profissional, São Paulo, SP, Brazil.

\section{Corresponding author:}

Rodrigo Jensen

Departamento de Enfermagem, Faculdade de Medicina de Botucatu, Universidade Estadual Paulista "Júlio de Mesquita Filho"

Distrito de Rubião Júnior, s/n. CEP 18618-970 - Botucatu, SP, Brazil rjensen@fmb.unesp.br

\section{ABSTRACT}

Objective: To identify informatics abilities essential to decision making in nursing management. Method: Survey study with specialist nurses in health informatics and management. An electronic questionnaire was built based on the competencies Information Literacy (five categories; 40 abilities) and Information Management (nine categories; 69 abilities) of the TIGER - Technology Informatics Guiding Education Reform - initiative, with the guiding question: Which informatics abilities are essential to decision making in management? Answers were sorted in a Likert scale, ranging from 1 to 5 . Rasch analysis was conducted with the software WINSTEPS ${ }^{\circledR}$. Results were presented in logits, with cutoff value zero. Results: Thirty-two specialists participated, coming from all regions of Brazil. In the information literacy competency, 18 abilities were considered essential and in Information Management, 38; these were sorted according to their degree of essentiality. Conclusion: It is believed that the incorporation of these abilities in teaching can support the education of nurse managers and contribute to evidence-based practice, incorporation of information and communication technologies in health and information management.

\section{DESCRIPTORS}

Nursing Informatics; Nursing Administration Research; Competency-Based Education. 


\section{INTRODUCTION}

In the beginning of the $21^{\text {st }}$ century, The Institute of Medicine of the National Academy of Sciences of the USA (IMNAS), when discussing the education of health workers in the USA, suggested that, in order to meet the demands of this century's healthcare system, these professionals would have to dominate a recommended set of essential competencies, using the concept of competency as the habitual and discerning use of communication, knowledge, technical skills, clinical reasoning, emotions, values and reflection in daily practice. One of the competencies that are essential in the education of health workers in this century, according to the IMNAS and the American Association of Colleges of Nursing, is the use of information technology to support decision making ${ }^{(1-2)}$.

Based on this, the initiative Technology Informatics Guiding Education Reforms, also known by the acronym TIGER $^{(3)}$, was created in 2004. It gathered nurses from many countries with the aim of developing a shared vision, strategies and specific actions to improve nursing practice, education and the offering of care mediated by information and communication technologies (ICTs) in health, supporting the nurses' decision making.

In Brazil, decision making is highlighted in the $\mathrm{Na}^{-}$ tional Curriculum Guidelines of Nursing Undergraduate Courses as one of the general competencies that determine the training of nurses, composed of clinical and managerial activities ${ }^{(4)}$. The same guideline proposes that health workers' practice must be based on the capacity for decision making, be them clinical or managerial. For that end, these professionals must possess competencies and abilities to assess, systematize and decide the most adequate actions, based on scientific evidence.

With the current perspectives of expansion of communication means, of methods for quick dissemination of knowledge and potential in the use of ICTs, the decisionmaking process of nurses changed. New knowledge, skills and attitudes became part of decision making in nursing management.

In accordance with the National Agenda of Priorities in Health Research ${ }^{(5)}$, which considers as priority the development of educational methods and strategies for the training and education of health workers, this study had the aim of identifying informatics abilities essential to decision making in nursing management.

\section{METHOD}

This study's development originated from the model of informatics competencies of the TIGER initiative ${ }^{(3)}$, which has three levels of competencies: Basic computer, Information literacy and Information management. The competencies Information literacy and Information management, conceptualized in the following definition, were part of this study. The competency Information literacy comprehends a collection of 40 abilities, presented in five categories, that make it possible to recognize when information is needed and to locate, evaluate and use that information appropri- ately. This is the ability of: identify information needed for a specific purpose; locate pertinent information; evaluate the information; and apply it correctly. In turn, the competency Information management comprehends a collection of 69 abilities presented in nine categories, and is defined as a process that consists of: (i) collecting data; (ii) processing the data; and (iii) presenting and communicating the processed data as information or knowledge ${ }^{(3)}$.

\section{ReSEARCH DESIGN}

This is a survey study with specialist Brazilian nurses in the fields of health informatics and nursing management. All participating specialists declared mastery of the English language in reading and met at least one of the following inclusion criteria: occupying/having occupied a leadership position in a healthcare institution; teaching/having taught management content in healthcare/nursing in a higher education institute; being researchers in the field of administration in healthcare/nursing; or considering themselves specialists in the theme at hand.

The construction of the questionnaire originated in the competencies model of the TIGER initiative ${ }^{(1)}$. The 40 abilities of the Information literacy competency and the 69 abilities of the Information management competency were part of the questionnaire. The following question guided the answers to the questionnaire: Which informatics abilities are essential to decision making in management? Answers were shown in a Likert scale; the level of essentiality attributed to each ability was presented as an ordinal variable and only the extreme values ( 1 and 5) were sorted, indicating the direction of the scale, namely: 1 (non-essential), 2, 3, 4 and 5 (essential).

Since the TIGER ${ }^{(3)}$ competencies are not yet available in the Portuguese translation, the abilities in the questionnaire were kept in their original language, English. The questionnaire was constructed in two stages. The first addressed the abilities of the Information literacy competency in managerial decision making, presented in the five categories proposed by the TIGER ${ }^{(3)}$ initiative. The second stage addressed the abilities of the Information management competency in managerial decision making and was presented in nine categories ${ }^{(3)}$. A pre-test of the questionnaire, to assess clarity and pertinence, was conducted with nine nurses of the Study Group for Education and Tele-Nursing Practices (Grupo de Estudos de Práticas de Educação e TeleEnfermagem - GEPETE) of the School of Nursing of the University of São Paulo. The questionnaire was analyzed in a meeting of the group.

In order to choose the specialists who would be invited to participate in the study, we researched authors of publications in the field of interest, consulted lists of participation in scientific events in the field and requested suggestions of names to specialists. The invitation for participating in the study was sent by e-mail and questions were answered individually, through the electronic questionnaire Survey Monkey ${ }^{\oplus}$. A glossary with 38 translated terms was offered.

The study followed the recommendations of Resolution No. 466/2012 of the National Health Council and 
was approved by the Research Ethics Committee of the School of Nursing of the University of São Paulo (CAAE: 15105013.9.0000.5392). The specialists agreed to participate in the study by signing a Free and Informed Consent Form.

\section{Data Analysis}

Answers were submitted to Rasch analysis, considering the categories of each competency. Rasch analysis allows calibration of the items' difficulty and the subjects' abilities independently, but using the same measurement unit, the $\operatorname{logit}(\log \text {-odds })^{(6-7)}$. For Rasch analysis to be carried out, the following presuppositions must be observed: the items should measure only one latent feature (unidimensionality) and the answer to one item must not be associated with the answer of another item (local independence) ${ }^{(8-10)}$.

Rasch analysis for polytomous data was carried out with WINSTEPS $^{\oplus}$ software, version 3.69.0 $0^{(11)}$. We initially investigated unidimensionality in each category. Afterwards, we estimated scale adjustment, person reliability and item reliability (abilities). InFit and OutFit statistical adjustment values between 0.5 and 1.5 and residual between -2 and +2 were considered adequate ${ }^{(11)}$.

The main goal of Rasch analysis in the study was to identify essential abilities among those proposed by the TIGER initiative ${ }^{(3)}$. Item (abilities) measurement in the scale presented a variation of -3 to 3 , which indicated their degree of essentiality, sorting them from the most essential to the less essential, respectively. For the cutoff value of essential abilities, we adopted the zero logit value, thus considering those lower than zero essential.

\section{RESULTS}

Thirty-two specialists participated in the study. They were predominantly female $(30 ; 94 \%)$, with a mean age of 43 years (SD 9.4), and nursing undergraduates (32; 100\%), with a mean length of professional practice of 20 years (SD 9.7) and with the highest academic ranks being Masters' (13; 41\%) or Doctorate degrees $(11 ; 34 \%)$. The latter predominantly practiced in educational activities $(22 ; 69 \%)$ and/or research $(15 ; 47 \%)$ in higher education institutions $(21 ; 65 \%)$ and/or hospitals $(12 ; 37 \%)$ with a public nature $(24 ; 75 \%)$, with a mean professional practice of 11 years (SD 8.8). Specialists from all regions of Brazil participated: Southeast (26;81\%), Northeast $(2 ; 6 \%)$, South $(2 ; 6 \%)$, Center-West $(1 ; 3 \%)$ and North $(1 ; 3 \%)$.

Table 1 presents results of Rasch analysis addressing dimensionality, scale adjustment, person reliability and item reliability referring to the categories of abilities in Information literacy and Information management.

Table 1 - Rasch analysis by categories of abilities in Information Literacy and Information Management, essential to decision making in nursing management - São Paulo, SP, Brazil, 2015.

\begin{tabular}{|c|c|c|c|}
\hline Information literacy & $\begin{array}{l}\text { Eigenvalue at } 1^{\text {st }} \\
\text { contrast }\end{array}$ & $\begin{array}{l}\text { Person } \\
\text { reliability }\end{array}$ & Item reliability \\
\hline $\begin{array}{l}\text { Category 1: Knowledge - Determine the nature and extent of the information } \\
\text { needed }\end{array}$ & $<3$ & * & * \\
\hline Category 2: Access - Access needed information effectively and efficiently & $<3$ & 0.60 & 0.16 \\
\hline $\begin{array}{l}\text { Category 3: Evaluate information and its sources critically and incorporate } \\
\text { selected information into his or her knowledge base and value system }\end{array}$ & $<3$ & 0.64 & 0.43 \\
\hline $\begin{array}{l}\text { Category 4: Individually or as a member of a group, use information } \\
\text { effectively to accomplish a specific purpose }\end{array}$ & $<3$ & 0.45 & 0.69 \\
\hline Category 5: Evaluate outcomes of the use of information & $<3$ & 0.39 & 0.73 \\
\hline \multicolumn{4}{|l|}{ Information management } \\
\hline Category 1: Demographic/patient info & $<3$ & 0.70 & 0.66 \\
\hline Category 2: Consents and authorizations & $<3$ & * & $*$ \\
\hline Category 3: Medication management & $<3$ & 0.84 & 0.86 \\
\hline Category 4: Planning care & $<3$ & 0.78 & 0.85 \\
\hline Category 5: Order/Results management & $<3$ & 0.73 & 0.85 \\
\hline Category 6: Care documentation & $<3$ & * & * \\
\hline Category 7: Decision support & $>3$ & 0.83 & 0.42 \\
\hline Category 8: Notifications & $<3$ & 0.56 & 0.82 \\
\hline Category 9: Facilitating communications & $<3$ & 0.51 & 0.66 \\
\hline
\end{tabular}

*it was not possible to calculate, most items had extreme answers. Note: $(n=32)$.

Each category was analyzed as a subscale, since they address a particular aspect of the abilities at hand. Unidimensionality was verified in all categories, except for category 7 of the Information management competency, which pre- sented more than one component at first contrast, according to results of principal component factor analysis.

Of the essential abilities in the Information literacy competency, only item 4.5 (on Table 2) presented an InFit 
value over 1.5; the items 3.7, 5.6 and 5.8 (on Table 2) presented OutFit values over 1.5, indicating lack of adjustment of the Rasch model. No abilities of the Information literacy competency presented residue outside the adequate values.

In relation to essential abilities of the Information management competency, items 4.1, 5.6, 8.8 and 9.2 (Table 3) presented InFit values over 1.5; items 4.1, 5.3, 5.6, 7.4, 7.12, 7.20 and 8.8 (Table 3) presented OutFit values over 1.5. Item 4.1 also presented excessive residue.

Table 2 presents the 18 abilities of the Information literacy competency with values under 0 logits. In other words, that reached a higher degree of essentiality.

Table 2 - Abilities of the Information Literacy Competency essential to decision making in nursing management - São Paulo, SP, Brazil, 2015.

\section{Category/Ability
Category 1: Knowledge - Determine the nature and extent of the information needed}

Ref. 1.1 Recognize a specific information need

Measure

Infit MnSq Oufit MnSq

Category 2: Access - Access needed information effectively and efficiently

Ref. 2.8 Understand that the Internet may be a useful resource for locating, retrieving and transferring information electronically

Ref. 2.3 Select types of information resources appropriate to a specific information need

Ref. 2.7 Use online search techniques and tools to locate relevant citations and to further refine the search

Ref. 2.6 Use search language appropriate to the source, such as a controlled vocabulary,

key words, natural language, author and title searches to locate relevant items in print and electronic resources

Category 3: Evaluate information and its sources critically and incorporates selected information into his or her knowledge base and value system

Ref. 3.11 Integrate the new information into existing body of knowledge

Ref. 3.5 Understand that the Internet may be a useful resource for locating, retrieving and transferring information electronically

Ref. 3.6 Use a variety of criteria, such as author's credentials, peer review, and reputation of the publisher, to assess the authority of the source

Ref. 3.7 Assess the relevance of a source to an information need by examining publication date, purpose, and intended audience

Ref. 3.8 Recognize omission in the coverage of a topic

$\begin{array}{lll}-0.66 & 1.20 & 0.96 \\ -0.56 & 0.50 & 0.33 \\ -0.29 & 0.90 & 1.07\end{array}$

$\begin{array}{lll}-0.20 & 0.70 & 0.59\end{array}$

Category 4: Individually or as a member of a group, use information effectively to accomplish a specific purpose

Ref. 4.8 Create a logical argument based on information retrieved

Ref. 4.5 Organize the information in a logical and useful manner

Ref. 4.1 Recognize and evaluate documentation for the information source, such as research methodology, bibliography or footnotes

Ref. 4.4 Recognize and accept the ambiguity of multiple points of view

$-0.85$

1.03

$-0.29$

1.14

$-0.19$

0.79

0.66

$-0.17$

1.24

0.86

$-0.01$

1.35

1.67

$-0.88$

0.70

0.60

$-0.68$

1.79

1.39

$-0.65$

0.88

1.02

$-0.23$

0.85

0.78

\section{Category 5: Evaluate outcomes of the use of information}

Ref. 5.5 Understand the ethics of information use, such as knowing how and when to give credit to information and ideas gleaned from others by appropriately citing sources in order to avoid plagiarism

Ref. 5.6 Respect intellectual property rights by respecting copyright

Ref. 5.8 Understand the social/political issues affecting information, such as:
a) privacy
b) privatization and access to government information
c) electronic access to information
d) the exponential growth of information
e) equal access to information

$\begin{array}{lll}-0.19 & 1.17 & 1.53 \\ -0.12 & 1.07 & 1.20\end{array}$

Ref. 5.1 Describe the criteria used to make decisions and choices at each step of the particular process used

Ref.=Reference code in the TIGER(3) material. Note: $(n=32)$.

Table 3 presents the 38 abilities of the Information management competency, with a value under 0 logits, in other words, abilities that reached a higher degree of essentiality. 
Table 3 - Abilities of the Information Management Competency essential to decision making in nursing management - São Paulo, SP, Brazil, 2015.

Category/Ability $\quad$ Measure Infit MnSq Oufit MnS

Category 1: Demographic/patient info

Ref. 1.1 Identify and Maintain a Patient Record

Ref. 1.7 Produce a Summary Record of Care

Ref. 1.9 Manage Patient History

Ref. 1.2 Manage Patient Demographics

Category 2: Consents and Authorizations

Ref. 2.3 Manage Consents and Authorizations

\section{Category 3: Medication Management}

Ref. 3.3 Manage Problem Lists

Ref. 3.5 Manage Medication Administration

Ref. 3.2 Manage Medication Lists

\section{Category 4: Planning Care}

Ref. 4.2 Manage Patient-Specific Care and Treatment Plans

Ref. 4.1 Interact with Guidelines and Protocols for Planning Care

Ref. 4.3 Interact with Clinical Workflow Tasking

\section{Category 5: Order/Results Management}

Ref. 5.6 Manage Results

Ref. 5.1 Manage Non-Medication Patient Care Orders

Ref. 5.2 Manage Orders for Diagnostic Tests

Ref. 5.3 Manage Orders for Blood Products and Other Biologics

\section{Category 6: Care Documentation}

Ref. 6.1 Manage Patient Clinical Measurements

Ref. 6.3 Manage Documentation of Clinician Response to Decision Support Prompts

Ref 6.4 Generate and Record Patient-Specific Instructions

\section{Category 7: Decision Support}

Ref. 7.2 Manage Health Information to Provide Decision Support for Patient Context- Driven assessments

Ref. 7.5 Interact with decision Support for Standard Care Plans, Guidelines, and Protocols

Ref. 7.3 Manage Health Information to Provide Decision Support for Identification of Potential Problems and Trends

Ref. 7.1 Manage Health Information to Provide Decision Support for Standard Assessments

Ref. 7.20 Interact with decision Support for Safe Blood Administration

Ref. 7.12 Interact with decision Support for Drug Interaction Checking

Ref. 7.10 Manage Health Information to Provide Decision Support for Self-Care

Ref. 7.4 Manage Health Information to Provide Decision Support for Patient and Family Preferences

Ref. 7.15 Interact with decision Support for Medication and Immunization Administration

Ref. 7.14 Interact with decision Support for Medication Recommendations

Ref. 7.16 Interact with decision Support for Non-Medication Ordering

Ref. 7.13 Interact with decision Support for Patient Specific Dosing and Warnings

Category 8: Notifications

$\begin{array}{lll}-0.71 & 0.91 & 0.79 \\ -0.68 & 0.86 & 0.87 \\ -0.59 & 0.75 & 0.71 \\ -0.43 & 1.28 & 1.18\end{array}$

$-0.61$

1.10

0.94

$-2.43$

0.75

0.16

$-1.17$

0.74

0.20

$-1.08$

0.94

1.00

$-2.41$

0.65

0.20

$-1.78$

2.92

9.90

$-0.06$

0.69

$-0.87$ 


\begin{tabular}{|c|c|c|c|}
\hline Category/Ability & Measure & Infit MnSq & Oufit MnSq \\
\hline Ref. 8.6 Manage Health Information to Provide Decision Support for Monitoring Response & -1.16 & 0.53 & 0.44 \\
\hline $\begin{array}{l}\text { Ref. } 8.5 \text { Manage Health Information to Provide Decision Support for Notification and Response } \\
\text { regarding population health issues }\end{array}$ & -0.56 & 0.74 & 0.58 \\
\hline Ref. 8.8 Access Healthcare Guidance & -0.33 & 1.58 & 1.67 \\
\hline $\begin{array}{l}\text { Ref. } 8.2 \text { Interact with decision Support for Notifications and Reminders for Preventive Services } \\
\text { and Wellness }\end{array}$ & -0.08 & 1.00 & 0.96 \\
\hline \multicolumn{4}{|l|}{ Category 9: Facilitating Communications } \\
\hline Ref. 9.4 Facilitate Patient, Family and Care Giver Education & -0.53 & 0.76 & 0.72 \\
\hline Ref. 9.1 Facilitate Inter-Provider Communication & -0.53 & 0.55 & 0.53 \\
\hline $\begin{array}{l}\text { Ref. 9.3 Facilitate Communications Between Provider and Patient and/or the Patient } \\
\text { Representative }\end{array}$ & -0.43 & 0.82 & 0.63 \\
\hline Ref. 9.2 Facilitate Provider -Pharmacy Communication & -0.23 & 1.53 & 1.43 \\
\hline
\end{tabular}

Ref.= Reference code in the TIGER(3) material. Note: $(n=32)$

*The items received maximum score from all specialists, it was not possible to obtain adjustment values.

Items 7.20 and 7.12 of the Information management competency presented the same essentiality level,

\section{DISCUSSION}

With the aim of contemplating various scenarios of health care in Brazil, specialist nurses from all regions of Brazil were involved in the study. The predominance of specialists from the southeast region follows the distribution of masters and doctors in Brazil ${ }^{(12)}$.

Factors such as length of practice (mean of 20 years) and academic rank ( $75 \%$ masters or doctors) are related to the study's inclusion criteria - which demanded specialist knowledge from participants, professional experience and mastery of the English language - and suggests consistency in the group's grasp of the theme. The same happens with the fact that they predominantly practice in public institutions of higher education, in teaching and research activities.

In comparison to recent studies that investigated informatics competencies in nursing using opinions from a board of specialists, this study has a higher ${ }^{(13)}$ or similar ${ }^{(14)}$ number of specialists and a higher academic rank among participants ${ }^{(13)}$.

Regarding the pertinence of Rasch analysis, only category 7 of the Information management competency did not present unidimensionality verified through factor analysis. Of the 41 abilities of the Information literacy competency, only one item presented an inadequate InFit value (the statistic that most lowers the measure). As for the 69 abilities of the competency Information management, seven presented inadequate InFit values.

In the Information literacy competency, two abilities stood out with a higher degree of essentiality, with -1.93 logits (Understand the ethics of information use, such as knowing how and when to give credit to information and ideas gleaned from others by appropriately citing sources in order to avoid plagiarism) and -1.16 logits (Respect intellectual property rights by respecting copyright), both of Evaluate outcomes of the use of information categorie. as well as items 7.10 and $7.4 ; 7.16$ and 7.13 ; and 9.4 and 9.1 .

Abilities considered essential ( $<0$ logits) were related to the understanding of the ethical use of information and intellectual respect of the information sources; to the recognition of the necessity of information use; to the use of tools such as the Internet and online search techniques; to educated decision making in the process of information search; to strategies to find, organize, interpret and use information; and to the assessment of relevance, quality and reliability of information.

The ethical use of information based on principles such as beneficence, autonomy and justice can favor the construction of effective interprofessional communication and collaboration, as well as the management and use of information and technology resources in health ${ }^{(15)}$. Intellectual respect and poor scientific behavior have been discussed, especially in the academic context, as well as policies for control, in countries from the European Union and the US ${ }^{(16)}$.

Abilities for recognizing the need for information, search, organization, interpretation, assessment and use have a direct relationship with abilities of evidence-based nursing $(\mathrm{EBN})$. These are centered on the capacity to identify issues related to decision making, to search for scientific information relevant for a question and to assess the validity of information ${ }^{(17)}$. It highlights the need for training on the use of ICTs - search tools, search strategies in databases and critical analysis of scientific articles for incorporating $\mathrm{EBN}$ in the nurses' practice. A study conducted with Korean nurses highlights the importance of training for the use of EBN, especially for young nurses and those who are not graduated in stricto-sensu programs ${ }^{(18)}$. However, in Brazil, a diagnosis of ICT training ${ }^{(19)}$ shows that the theme is still incipient and underappreciated in the curriculum of nursing undergraduate programs.

In the Information management competency, two abilities stood out with higher values for essentiality, one with 
-2.43 logits (Manage problem lists) and another with -2.41 logits (Manage individualized care and care plans). Essential abilities addressed were: management of clinical and demographic data; the use of systems for decision support; management of clinical and administrative documentation; management of care plans; use of clinical protocols; facilitation of communication and education of users and workers; interaction with the flow of clinical work.

The ability Manage problem lists (category: Medication Management), has been discussed mainly in complex contexts, such as clinical research, taking into consideration data gathering, codification and analysis ${ }^{(20)}$. Management of individualized care and care plans, as well as data generated by these reports, has been employed as a strategy for the development of clinical studies that begin with the electronic data from the systems used in hospitals, generating indicators and assessments ${ }^{(21)}$.

It is worthy emphasizing that abilities in data management, use of systems for decision support and communication resources among professionals have been recognized as relevant abilities in the context of nurse managers for almost two decades ${ }^{(22)}$ and are still being discussed ${ }^{(14)}$.

Information management abilities identified as essential are similar to those in Brazilian publications that discuss management competencies of nurses ${ }^{(23-25)}$. It is inferred that, in Brazil, the construction of the abilities of this competency happen, mainly, in stricto-sensu graduate programs. The importance of nursing graduate programs offering content and courses related to ICTs should be emphasized.

A study carried out in China with 68 nurse managers found that these professionals had a moderate level of competency in informatics. In the study, an association was shown among the variables level of education, management experience, informatics training and the level of information literacy competency of the nurse managers. It also recommended efforts for the training of these professionals ${ }^{(26)}$. There is also a discussion about the training of nursing students for the use of ICTs and the relevance of preparing them for practicing in a scenario of care with technological resources ${ }^{(14)}$.

A previous study ${ }^{(27)}$ investigated the scientific production related to informatics competencies for the decision making of nurse managers. The study highlighted gaps in the theme and that its discussion in literature is still incipient. With that, the model of competencies of the TIGER initiative, a project birthed through international cooperation $^{(3)}$, adds to the field of scientific knowledge in nursing by presenting a set of informatics competencies relevant for the training of nurses.

With this large list of competencies established, this study brings an original Brazilian contribution to the TIGER initiative by measuring the level of essentiality of each ability in the list and proposing its sorting, identifying the main abilities among them in the context of nurse management. We believe that there is variation in diverse specialty scenarios. The definition of essential abilities is relevant for the various specialties in the field, aiming at the cross-sectional teaching of these competencies in the nursing curriculum.

The identification of abilities essential to the decision making of nurse managers is expected to influence the fields of education, management and research. In education, it acts by offering resources for educators to recognize relevant content for the training of nurse managers; in management, by favoring sensible use of ICTs in work process and hiring of personnel; in research, by supporting future studies that discussing ICTs in the field of nurse management and enabling comparisons to other countries.

This study's results are exploratory and introductory. Its limitations were the small sampling size and the abilities of the Information literacy and Information management competencies presented in English to the specialists. For future studies, we recommend a higher number of specialists, a higher national representation and the reapplication of the study in other areas of nursing practice; we also recommend the translation and cultural adaptation for Portuguese of competencies of the TIGER initiative.

\section{CONCLUSION}

The production of data, information and knowledge in health, as well as the use of ICTs, has been exponentially growing. Facing this reality, we should rethink the training of nurse managers and their role in health services. This study made it possible to identify, between the competencies Information literacy and Information management, proposed by the TIGER initiative, informatics abilities essential to the decision making of nurse managers in Brazil. Assessed items were adjusted to the Rasch analysis model and it was possible to sort and measure the degree of essentiality of the abilities.

In the Information literacy competency, we identified 18 essential abilities, which addressed the ethical use of information and intellectual respect, the need to use information and the Internet, search strategies, organization and interpretation of information and assessment of its quality/reliability. It is inferred that these abilities are directly related to evidence-based practice.

In the competency Information management, 38 abilities were identified as essential for nurse managers' decision making, comprising a set of abilities composed of management of clinical/demographic data, clinical/administrative documentation and care plans, use of systems for decision support and for clinical protocols, facilitation of communication and education of users and professionals and interaction with the flow of clinical work. It is worth noting the importance of encouraging the education of nurses in Brazil on competencies of data bank and information management that support managerial decisions.

We believe that the incorporation of these abilities in teaching can support the training of nurse managers and contribute to evidence-based practice and the incorporation of ICTs and information management. 
RESUMO

Objetivo: Identificar as habilidades de informática essenciais à tomada de decisão no gerenciamento em enfermagem. Método: Estudo survey com enfermeiros especialistas em informática em saúde e gerenciamento. Foi construído questionário eletrônico baseado nas competências Informacional (cinco categorias; 40 habilidades) e Gestão da Informação (nove categorias; 69 habilidades) da iniciativa TIGER - Tecnologia da Informação Guiando a Reforma Educacional, partindo da pergunta: Quais são as habilidades de informática essenciais para a tomada de decisão no gerenciamento? Respostas foram indicadas em escala Likert, variando de 1 a 5 . Foi realizada análise Rasch com o software WINSTEPS, os resultados foram apresentados em logits, com valor de corte zero. Resultados: Participaram 32 especialistas, com representação de todas as regiões do Brasil. Na competência Informacional 18 habilidades foram consideradas essenciais e na Gestão da Informação 38 habilidades; estas foram ordenadas segundo seu grau de essencialidade. Conclusão: Acredita-se que a incorporação dessas habilidades no ensino possa sustentar a formação de enfermeiros gestores e contribuir com a prática baseada em evidências, incorporação de tecnologias de informação e comunicação em saúde e gestão da informação.

\section{DESCRITORES}

Informática em Enfermagem; Pesquisa em Administração de Enfermagem; Educação Baseada em Competências.

\section{RESUMEN}

Objetivo: Identificar las habilidades de informática esenciales a la toma de decisión en la gestión en enfermería. Método: Estudio survey con enfermeros especialistas en informática en salud y gestión. Fue construido cuestionario electrónico basado en las competencias Informacional (cinco categorías; 40 habilidades) y Gestión de la Información (nueve categorías; 69 habilidades) de la iniciativa TIGER Tecnología de la Información Guiando la Reforma Educativa, partiendo de la pregunta: ¿Cuáles son las habilidades de informática esenciales para la toma de decisión en la gestión? Las respuestas fueron indicadas en escala Likert, variando de 1 a 5 . Se llevó a cabo el análisis Rasch con el software WINSTEPS, los resultados fueron presentados en logits, con punto de corte cero. Resultados: Participaron 32 expertos, con representación de todas las regiones de Brasil. En la competencia Informacional, 18 habilidades fueron consideradas esenciales y, en la Gestión de la Información, 38 habilidades; estas fueron ordenadas según su grado de esencialidad. Conclusión: Se cree que la incorporación de dichas habilidades en la enseñanza pueda sostener la formación de ingenieros gestores y contribuir a la práctica basada en evidencias, incorporación de tecnologías de información y comunicación en salud y gestión de la información.

\section{DESCRIPTORES}

Informática Aplicada a la Enfermería; Investigación en Administración de Enfermería; Educación Basada en Competencias.

\section{REFERENCES}

1. Institute of Medicine (IOM). Health professions education: a bridge to quality. Washington: National Academy Press; 2003.

2. American Association of Colleges of Nursing (AACN). The essentials of baccalaureate education for professional nursing practice [Internet]. Washington: AACN; 2008 [cited 2015 May 26]. Available from: http://www.aacn.nche.edu/education-resources/BaccEssentials08.pdf

3. Technology Informatics Guiding Education Reform. The TIGER initiative: informatics competencies for every practicing nurse: recommendations from the TIGER collaborative [Internet]. 2014 [cited 2015 May 26]. Available from: http://www.thetigerinitiative.org/ docs/TigerReport_InformaticsCompetencies_001.pdf

4. Brasil. Ministério da Educação; Conselho Nacional de Educação. Resolução n. 3, de 07 de novembro de 2001. Institui as Diretrizes Curriculares Nacionais do Curso de Graduação em Enfermagem [Internet]. Brasília; 2001 [citado 2015 maio 26]. Disponível em: http:// portal.mec.gov.br/cne/arquivos/pdf/CES03.pdf

5. Brasil. Ministério da Saúde; Secretaria de Ciência, Tecnologia e Insumos Estratégicos, Departamento de Ciência e Tecnologia. Agenda Nacional de Prioridades de Pesquisa em Saúde. Brasília: MS; 2008.

6. Smith EV Jr, Conrad KM, Chang K, Piazza J. An introduction to Rasch measurement for scale development and person assessment. J Nurs Meas. 2002;10(3):189-206.

7. Conrad KJ, Smith EV. International conference on objective measurement applications of Rasch analysis in health care. Med Care. 2004;42(1 Suppl I):1-6.

8. Rocha NS, Chachamovich E, Fleck MPA, Tennant A. An introduction to Rasch analysis for psychiatric practice and research. J Psychiatr Res. 2013;47(2):141-8.

9. Chang C, Reeveltem BB. Item response theory and its applications to patient-reported outcomes measurement. Eval Health Prof. 2005;28(3):264-82.

10. Hagquist C, Bruce M, Gustavsson JP. Using the Rasch model in nursing research: an introduction and illustrative example. Int J Nurs Stud. 2009;46(3):380-93.

11. Linacre J. A user’s guide to Winsteps \& Ministeps: Rasch Model Computers Programs. Chicago, IL: Winsteps; 2009.

12. Brasil. Ministério da Educação; Instituto Nacional de Estudos e Pesquisas Educacionais Anísio Teixeira. Censo 2014. Brasília, DF: MEC/ INEP; 2014.

13. Collins SA, Alexander D, Moss J. Nursing domain of Cl governance: recommendations for health IT adoption and optimization. J Am Med Inform Assoc. 2015;22(3):697-706.

14. Nagle LM, Crosby K, Frisch N, Borycki E, Donelle L, Hannah K, et al. Developing entry-to-practice nursing informatics competencies for registered nurses. Stud Health Technol Inform. 2014;201:356-63.

15. Byrd GD, Winkelstein P. A comparative analysis of moral principles and behavioral norms in eight ethical codes relevant to health sciences librarianship, medical informatics, and the health professions. J Med Libr Assoc. 2014;102(4):247-56. 
16. Fierz K, Gennaro S, Dierickx K, Van Achterberg T, Morin KH, De Geest S. Scientific misconduct: also an issue in nursing science? J Nurs Scholarsh. 2014;46(4):271-80.

17. Domenico EBL, Ide CAC. Enfermagem baseada em evidências: princípios e aplicabilidades. Rev Latino Am Enfermagem. 2003;11(1):115-8.

18. Hwang JI, Park HA. Relationships between evidence-based practice, quality improvement and clinical error experience of nurses in Korean hospitals. J Nurs Manag. 2015;23(5):651-60.

19. Sanches LMP, Jensen R, Monteiro MI, Lopes MHBM. Informatics teaching in undergraduate nursing programs at Brazilian public institutions. Rev Latino Am Enfermagem. 2011;19(6):1385-90.

20. Richesson RL. An informatics framework for the standardized collection and analysis of medication data in networked research. J Biomed Inform. 2014;52:4-10.

21. Cohen B, Vawdrey DK, Liu J, Caplan D, Furuya EY, Mis FW, et al. Challenges associated with using large data sets for quality assessment and research in clinical settings. Policy Polit Nurs Pract. 2015;16(3-4):117-24.

22. Sinclair VG. Informatics knowledge: the key to maximizing performance and productivity. Semin Nurse Manag. 1997;5(2):91-6.

23. Cunha ICKO, Ximenes NFRG. Competências gerenciais de enfermeiras: um novo velho desafio? Texto Contexto Enferm. 2006;15(3):479-82.

24. Furukawa PO, Cunha ICKO. Profile and competencies of nurse managers at accredited hospitals. Rev Latino Am Enfermagem. 2011;19(1):106-14.

25. Manenti SA, Ciampone MHT, Mira VL, Minami LF, Soares JMS. The construction process of managerial profile competencies for nurse coordinators in the hospital field. Rev Esc Enferm USP. 2012;46(3):722-8.

26. Yang L, Cui D, Zhu X, Zhao Q, Xiao N, Shen X. Perspectives from nurse managers on informatics competencies. Scientific World J. 2014;2014:391714.

27. Jensen R, Casteli CP, Kobayashi RM, Leite MM. Informatics competencies in nursing management. Stud Health Technol Inform. 2015;216:1013.

Acknowledgements: We thank the specialists who contributed their knowledge for the development of this study, the members of the Study Group for Education and Tele-Nursing Practices (Grupo de Estudos de Práticas de Educação e Tele-Enfermagem - GEPETE) of the Escola de Enfermagem, Universidade de São Paulo.

Financial Support: Conselho Nacional de Desenvolvimento Científico e Tecnológico (CNPq). Process 500548/2013-7. 